\title{
Needs assessment in a rural community on a commercial farm in South Africa
}

\author{
Cisca Green, Pricilla Botha \& Hettie C Schönfeldt
}

\section{OPSOMMING}

' $n$ Behoeftebepaling is onderneem om die nasionale bevinding van die teenwoordigheid van voedingsprobleme op kommersiële plase te bevestig. Die teikengroep was die jong kind (geboorte tot 10 jaar) woonagtig op die plaas, alhoewel die vroulike hoof van die huishoudings waar hierdie kinders woon die werklike informante was. Spesifieke doelwitte is geformuleer naamlik om die (a) gemeenskap te beskryf (b) bepaalde voedingsprobleme te identifiseer (c) hierdie probleme na aanspreekbare behoefte om te skakel en (d) 'n basis te skep waarvandaan ' $n$ geskikte intervensie beplan kon word. Verskeie data-insamelingsaktiwiteite is onderneem in aggenome die waarde van Deelnemende Aksie Navorsing in behoeftebepalingstudies. Die proses van behoeftebepaling is in hierdie studie deur ' $n$ inligtingspiramiede gelei. Die navorsingspan het relevante inligting versamel om probleme en behoeftes te identifiseer en te prioritiseer asook inligting om die kwaliteit van intervensiebeplanning en implementering te verbeter. Die kwaliteit en verskeidenheid van dieetinname in die gemeenskap was kommerwekkend. Verdere ondersoek het ' $n$ behoefte aan gedragsverandering in higiëne en sanitêre praktyke getoon. Ander probleme was die waarneembare voedsel insekuriteit en aspekte rakende voedselhanteringstrategieë. Hierdie probleme is tydens ' $\mathrm{n}$ reeks besprekings gesorteer en geprioritiseer. Met die hulp van ' $n$ veldwerker en sleutel informant is geïdentifiseerde probleme na voelbare behoeftes omgeskakel, wat deur die gemeenskap verstaan en aanvaar is.

\section{- Mrs F Green}

Department of Consumer Science

University of Pretoria

\section{- Prof P Botha}

Department of Consumer Science

University of Pretoria

\section{- Prof HC Schönfelt}

Centre for Nutrition

Faculty of Natural and Agricultural Sciences

University of Pretoria

\section{INTRODUCTION}

Results from the National Food Consumption Survey (Labadarios, 2000) show that the majority of South African households live in poverty, with a limited variety of foods (mainly staples) available in the home. Findings from this study also indicate that one out of two children has an energy intake less than two thirds of their energy needs, and that a great number of children consume a diet with too poor a nutrient density, to meet their nutrient (macro and micro) requirements. Stunting and underweight (the country's most prevalent nutritional disorders), are most severe in children one to three years of age, especially in those living in rural communities, and particularly those children living on commercial farms.

The above-mentioned findings were the main motivation behind this study and were used to demarcate the research field to rural communities on commercial farms. A research team from the University of Pretoria (Department of Consumer Science) conducted a 'needs assessment' in a community on a commercial farm situated between the towns of Clarens and Fouriesburg in the North Eastern Free State province. This team consisted of a senior researcher (also the supervisor of the study), the primary researcher (a PhD student) and a fieldworker (a Master's student). A convenient sampling method was used to select this particular farm, which served as a starting point for this investigation.

The aim of this study was to conduct a situation analysis, to verify the national finding of the existence of nutritional problems on commercial farms. Certain assumptions underscore this study. Firstly, that nutritional problems actually exist on the farm; secondly that these problems can be defined as needs within the community, and thirdly that the community members are competent and able to be persuaded to address these needs. Specific objectives were stated as (a) to describe the community, (b) to identify particular nutrition problems, (c) to translate those problems into addressable needs, and (d) to establish a basis for designing suitable interventions. The process included making contact and obtaining access to the community, becoming knowledgeable about internal and external contextual factors (culture, available structures and resources), establishing funding, and ensuring support from the participants, research team members, farm owner and other stakeholders. Assessed needs and problems were discussed with the community, and priorities were set. The specific designing process did not form part of the 'needs assessment', and is therefore not further discussed. 
Young children (birth to 10 years) living on the selected commercial farm formed the target group, although the actual informants were the female heads of the households where these children live. Twenty children were within this age group. There were 18 homesteads on the farm, but only eight had children in the particular age group. Other adult female members of the households were also included as informants $(n=14)$ mainly to better understand the living conditions and environmental factors influencing the child. Other key-informants who were used as data sources included the previous and current owners of the farm, staff involved in rendering local health services, and the teachers from the local farm school.

\section{THEORETICAL BACKGROUND}

'Needs assessment' within a particular community can be defined as a process of getting involved in a community, with the aim of assisting community members to learn more about their own current situation, problems and needs, and to facilitate the development of goals and strategies for solving these problems. Problems identified within a community can only become concrete needs once they have been defined as such. Any assessment process should therefore demarcate the parameters of the how, when, and where of the identified problems. The process is also an effective means of assisting local people in their own problemsolving activities (Butler \& Howell, 1980).

The literature is replete with definitions related to the 'needs' concept. Various views of this concept are depicted in the literature to follow. From an educational point of view, Caffarella (1994:75) and Tyler (in Boone et al, 2002:143), defines a need as the difference between the present condition of an individual or group and a more acceptable norm. Needs may also be arranged from the lowest and most fundamental to the highest (Maslow, 1970, in Boone et al, 2002:143). Within this hierarchy, a higher-level need (like self esteem) cannot be achieved until the individual has attained some level of satisfaction of the needs below it. These lower level needs are considered basic to human existence, and include aspects relevant to this research study, such as nutrition and security. An individual cannot satisfy any higher-level need until the preceding needs have been satisfied.

Within the field of evaluative research, a 'needs assessment' answers questions about the social conditions in a community, which a program intends to address. Diagnostic activities are usually involved, such as assessing the nature, magnitude and distribution of a social problem. The extent to which there is a need for intervention to address the problem, and the implications of these circumstances for the design of the intervention are also included in this definition (Rossi et al, 1999:63).

Anthropologists differentiate between felt and real needs, where a felt need may refer to what a person would like to have. The standard or norm held by the community as being realistic to ensure a quality of life, usually influences felt needs. These needs however, are not necessarily a true reflection of the community's real needs. Real needs are considered those, when viewed objectively, (as by an independent observer) that should be met within a community to meet a specified aim. Meister (1972: 117) claimed that there are no felt needs in traditional African communities, but rather needs that are justified or dictated by tradition. Felt needs imply a measure of independence on the part of the individual, who freely expresses what he thinks, and such freedom is taboo in traditional communities. The result is that a list of only local objectives is prepared, where joint action will be required to achieve them. People also cannot want something that they do not know exists, and the more underprivileged people are, the less able they are to formulate ideas for their own development (Batten, in Wasserman \& Kriel, 1997:80; Bradshaw, 1972; McKillip, 1987:16).

The possibility does exist that community members can be educated or trained to experience an identified or assessed need as a felt need. The needs that emanate from this interaction are known as induced felt needs, persuaded needs, or educated needs (Wasserman \& Kriel, 1997:80). Within the assumption that community members can be assisted to develop the capacity to desire the things they really need, the process of 'needs assessment' for this study was performed.

\section{DATA GATHERING}

The gathering of information is a means to an end, and can never achieve meaning as an isolated exercise. Information gathering must be directly relevant to a planned intervention and must be done by the people participating in and carrying responsibility for the intervention. This is imperative for effective 'needs assessment'. Through participation, local knowledge is used as a solid base for development. If people do not participate in their own development, they have no affinity for developmental efforts and their results. The huge problem of sustainability of interventions is resolved if the affected people participate, knowing that they have a stake in the effort and the results. (Swanepoel, 1997:5). The methodological approach followed throughout the study will now be further highlighted.

\section{Approach}

Participation is one of the core principles of 'Participatory Action Research' (PAR), and implies that the subjects of study (respondents/participants) are integrated in the research by participating fully and actively in the research process. Research is thus transformed into an interactive communal enterprise (Collins, 1999:18; Fals-Borda, 1988:150). Scholars of PAR seem to agree that different degrees of participation can be discerned. At the one end of the scale, there is the position where participation means 'consulting' participants on the central aspects of the research study. The middle position on the scale re- 
flects the view of PAR functioning as a 'partnership' between researcher and participants, with decisionmaking and control being shared by all stakeholders. At the other extreme of the scale is the realm of what is termed 'participant control' referring to the participants who are in full control of the inquiry. The degree of participation that may be possible within a particular study is a function of a combination of factors. It will not be reasonable to demand full scale PAR to be achieved in all cases, or even the same degree of participation. Participation should, however, always be enhanced as much as possible.

Principles that also form part of PAR which were applied in this study are the following:

- The role of researcher as change agent.

- The democratic nature of the research relationship.

- How local knowledge is incorporated into the research.

- Knowledge, generated for purposes of action

- Ownership by the participants.

- Empowerment of the participants (Babbie \& Mouton, 2001:314, Whyte, 1995, 290; Whyte, 1991:97).

PAR is further cited as a cyclical, reflective process. The different elements and aspects can therefore not be arranged in a consecutive order. It may start with the awareness of a problem, including exploring a need for inquiry and deciding what the purpose of research would be. This may evolve from interactions with members and groups in the field or community. Decisions and findings, however, should make sense to the participants, and deployed in terms of their own language and in relation to their own perceptions and values (Seymour-Rolls \& Hughes, 1995). This study included PAR activities, but followed the sequence as depicted in the information pyramid (Figure 1). The PAR activities, with its revolving principles, formed part of the data-gathering process on each level.

Recognizing the values of PAR in needs-assessment studies, various data-gathering activities were undertaken. The methodologies used within each datagathering level are revealed in the next session. Data analysis was mainly interpretative, involving descriptions of the phenomena. The aim was to write objective accounts of fieldwork experiences within the specific context of nutrition intervention. Results follow subsequently.

\section{Various types of data required}

Before commencing a needs assessment, one has to decide which information is relevant to acquire. Various types of information can be useful to describe the nutritional situation of a community. These types of information include clinical examinations, anthropometrical data, dietary surveys, vital statistics, food availability, economic data, socio-cultural data, and scientific information relevant to food such as nutrient content, biological value and the presence of toxic or harmful factors such as aflatoxins and goitrogens (Latham, 1997:308). For this study, certain types of data were chosen and structured into a pyramid. The pyramid resembles the one used by Chopra and Cloete (2001:13) (see Figure 1) and was used to guide the data-gathering process of this study.

Information on a specific community and situation has little value if it is not seen against the milieu of all its external influences. Information on level one was required to place the proposed needs assessment in context. Information was retrieved during contactmaking sessions with the community, and was used to describe the community in terms of the indicated dimensions in Figure 1. These contact-making sessions were also purposeful to sensitise the community and the research team towards possible nutrition problems and needs.

Information on the next level specifically revolved around the nutrition situation within the community. Indicators used were nutritional status and health status of community members, household food security, and hygiene and sanitation practices within the community. These indicators are well accepted within the study field of community nutrition (Endres, 1999:254; Lee \& Nieman, 2003:3,4,163; Latham, 1997:9).

Conclusive information from level two was needed at level three to identify the felt and real/assessed needs of the community. The research team also required this information for further inquiry into these needs. The information was necessary to formulate and prioritise the different needs, and to provide direction regarding the planning and designing of a suitable, effective intervention. Level three also set the stage for the process to follow, namely to achieve consensus and agreement regarding the prioritised needs within the community. The identification and utilization of key informants and various stakeholders was also considered to be useful to transform assessed problems into felt or real needs.

\section{The first level of contextual information}

The needs of the community were identified in a formal and in an informal way, applying various techniques and methods. The informal way was termed 'contact-making' and started with the researcher's entrance into the area and becoming acquainted with the community and its members. The contact-making phase was also a natural progression from entry to intervention, a process that should evolve naturally. Contact-making usually is a crucial relationshipbuilding period, during which the stage is set for a community-based intervention to proceed. Momentum should be generated and sustained for motivation and enthusiasm to continue. Swanepoel (1997:71) advised to be as unobtrusive and as natural as possible, displaying empathy with, and interest in the people's situation.

Entrance to the farm was not disruptive but purposeful. The research team entered the community with the following strategy, namely to ensure that:

Community members get to know and accept the re- 


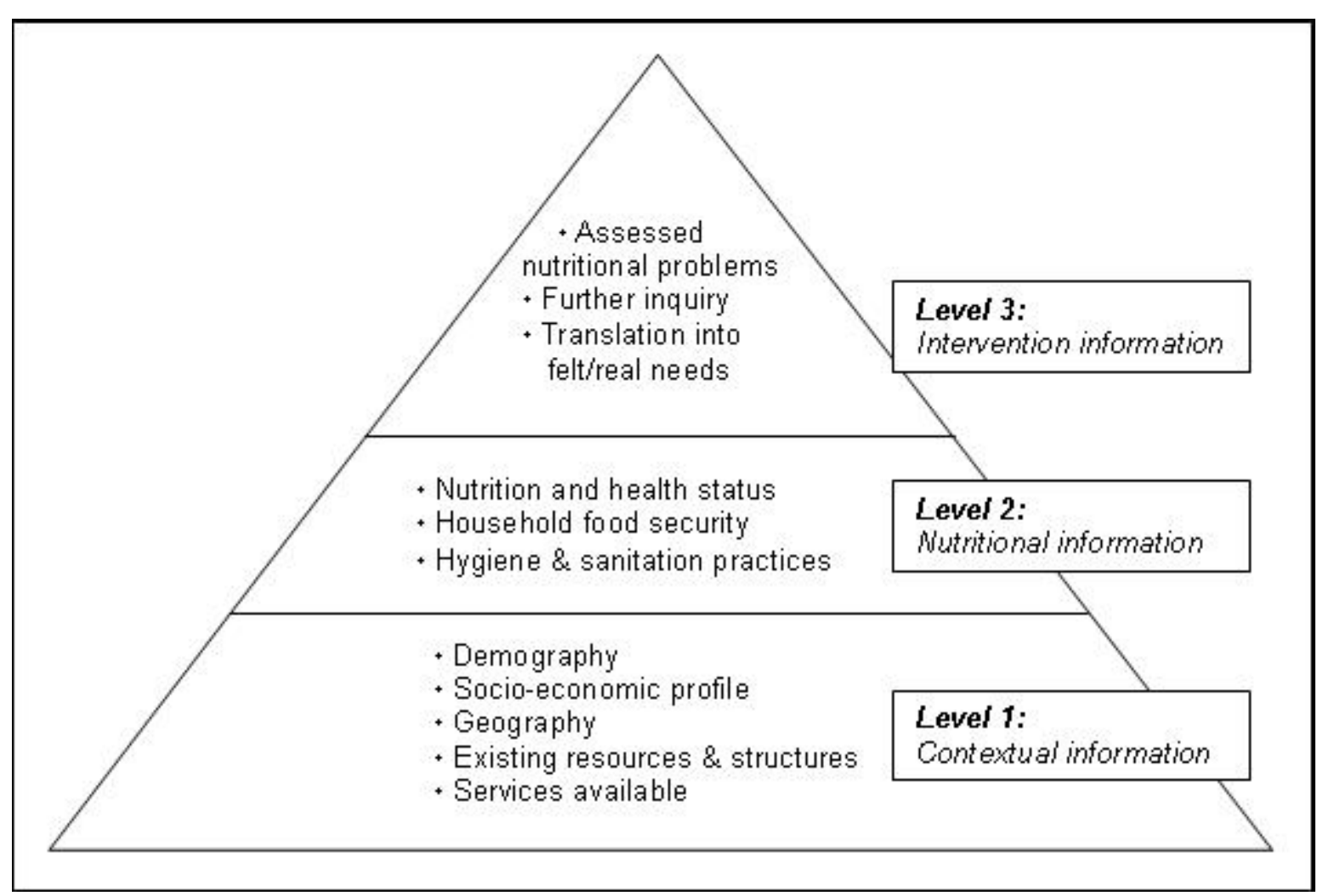

FIGURE 1: $\quad$ INFORMATION PYRAMID TO GUIDE DATA GATHERING

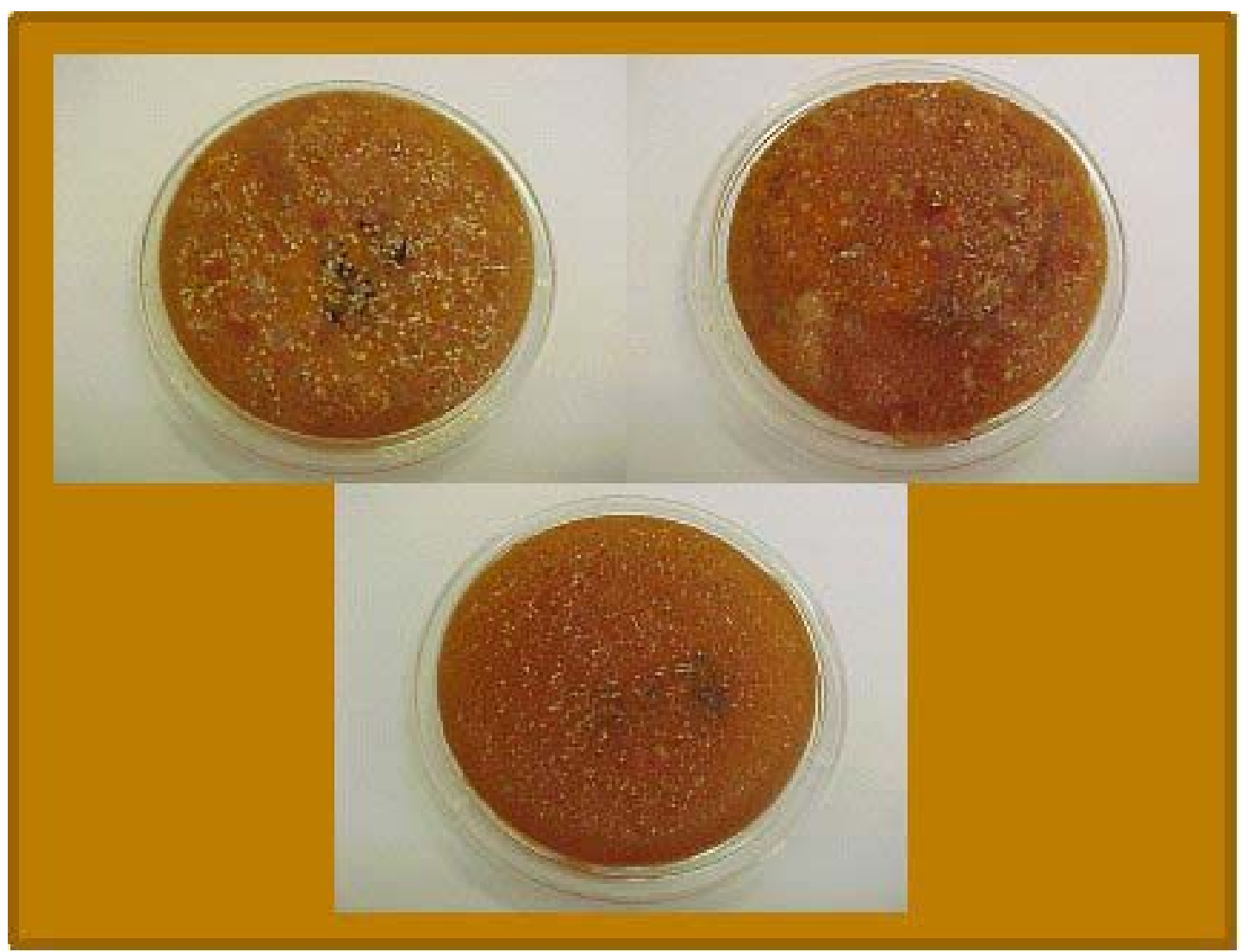

FIGURE 2: $\quad$ EXAMPLES OF BACTERIAL OVERGROWTH ON PLATES TAKEN FROM VARIOUS SURFACES IN 18 HOMESTEADS 


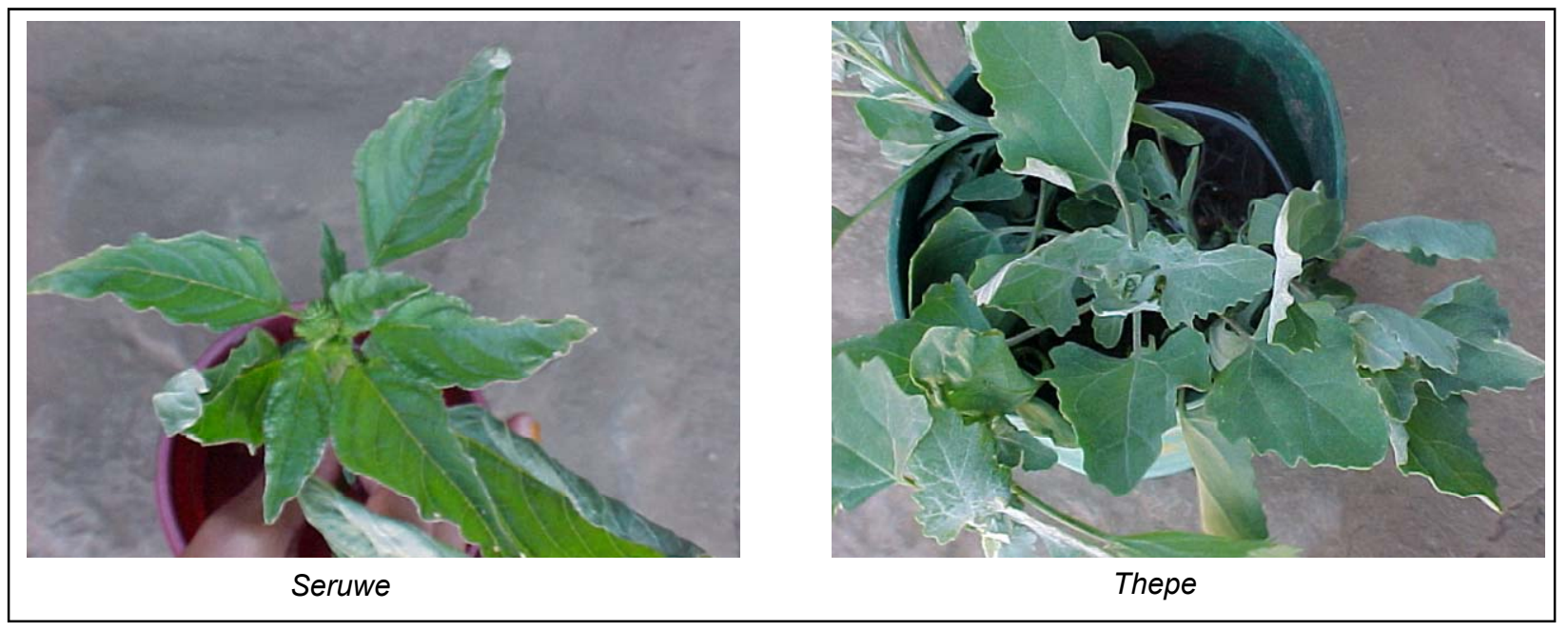

FIGURE 3: MOROGO VARIETIES ON THE FARM

TABLE 1: HYGIENE SCORING GUIDELINE

\begin{tabular}{|l|c|l|l|l|l|l|}
\hline Dimension & $\begin{array}{l}\text { Max } \\
\text { score }\end{array}$ & \multicolumn{4}{|c|}{ Typologies } \\
\hline $\begin{array}{l}\text { Personal } \\
\text { hygiene }\end{array}$ & 10 & Clean nails =2 & $\begin{array}{l}\text { Clean } \\
\text { clothes =2 }\end{array}$ & $\begin{array}{l}\text { Good body } \\
\text { odour =2 }\end{array}$ & $\begin{array}{l}\text { No reported } \\
\text { illnesses 2 }\end{array}$ & $\begin{array}{l}\text { No visible } \\
\text { sores =2 }\end{array}$ \\
\hline $\begin{array}{l}\text { Household } \\
\text { hygiene }\end{array}$ & 10 & $\begin{array}{l}\text { General clean } \\
\text { appearance=2 }\end{array}$ & $\begin{array}{l}\text { Good } \\
\text { ventilation=2 }\end{array}$ & $\begin{array}{l}\text { Washing } \\
\text { facilities } \\
\text { available=2 }\end{array}$ & $\begin{array}{l}\text { Clean kitchen } \\
\text { cloth=2 }\end{array}$ & $\begin{array}{l}\text { Presence of } \\
\text { soap=2 }\end{array}$ \\
\hline $\begin{array}{l}\text { Environmental } \\
\text { hygiene }\end{array}$ & 10 & $\begin{array}{l}\text { Children use } \\
\text { pit latrines=3 }\end{array}$ & $\begin{array}{l}\text { Rubbish } \\
\text { removal in } \\
\text { place=3 }\end{array}$ & Pets at bay=2 & $\begin{array}{l}\text { Chicken kept } \\
\text { in run=2 }\end{array}$ & \\
\hline
\end{tabular}

\section{TABLE 2: $\quad$ CRITERIA FOR PRIORITIZING NEEDS AND PROBLEMS}

(Sort as cited by Caffarella, 1994:89)

\begin{tabular}{|l|l|}
\hline Importance criteria & Description \\
\hline Number of people affected & An estimate of how many people would benefit if the problem were addressed \\
\hline Contribution to goals & $\begin{array}{l}\text { The degree to which addressing the problem will contribute to the attainment of } \\
\text { the study aim and community's priorities }\end{array}$ \\
\hline Immediacy & The degree to which each problem requires immediate attention \\
\hline Instrumental value & $\begin{array}{l}\text { The degree to which one problem will have a positive or negative effect on ad- } \\
\text { dressing other problems }\end{array}$ \\
\hline Magnitude of discrepancy & $\begin{array}{l}\text { The desirable size of the gap between the current situation and a more desirable } \\
\text { one }\end{array}$ \\
\hline Feasibility criteria & Description \\
\hline Efficacy & The degree to which an intervention can contribute to addressing the problem \\
\hline Availability of resources & $\begin{array}{l}\text { The degree to which the resources necessary to address the problem would be } \\
\text { available if it is decided that the problem should be addressed }\end{array}$ \\
\hline Commitment to change & $\begin{array}{l}\text { The degree to which those with vested interest (research team, participants and } \\
\text { stakeholders) are committed to addressing the problem }\end{array}$ \\
\hline
\end{tabular}




\section{BOX 1: CONTEXTUAL INFORMATION}

The farm covers an area of 1500 hectares, producing a variety of commodities like crops (maize, wheat), cattle (milk and meat), sheep (meat), fruit (apricots, peaches, cherries), and walnuts.

\begin{tabular}{|c|c|}
\hline Demography & $\begin{array}{l}\text { There were } 18 \text { homesteads on the farm, from which only } 8 \text { inhabited young children. } \\
\text { Nineteen children younger than } 10 \text { years were present. } \\
\text { All the participants }(n=23) \text { were Southern Sotho, adult females, living within the commu- } \\
\text { nity, and also speaking the local language. Only two women could understand Afrikaans } \\
\text { and three English. } \\
\text { All women were between } 24 \text { and } 64 \text { years of age. } \\
\text { All except two interviewees had some formal education. } \\
\text { The highest qualification varies between grade three (on primary school level) and one } \\
\text { respondent's daughter-in-law who finished grade twelve (secondary school level). } \\
\text { Households consisted of seven members on average. }\end{array}$ \\
\hline $\begin{array}{l}\text { Socio-economic } \\
\text { profile }\end{array}$ & $\begin{array}{l}\text { Labour on the farm is the main source of income providing jobs for } 4 \text { women and } 12 \text { men. } \\
\text { Average incomes of R600 per month per household were calculated. These incomes in- } \\
\text { cluded pensions and other maintenance received. In the households where members are } \\
\text { working on the farm, they also received an additional allowance of an eighty-kilogram bag } \\
\text { of maize meal per month } \\
\text { Household incomes are mainly from wages, as at least one of the household members is } \\
\text { employed on the farm. Farmers also are not in favour of people living on the farm if they } \\
\text { are not employed there, but do tend to make exceptions for family members and people } \\
\text { who have already been living there for a long time. The few products produced by them } \\
\text { (vegetables, fruit) contributed to their income in an indirect way. Outside funds were also } \\
\text { received. Three women received maintenance from their children's fathers who work in the } \\
\text { cities, and two older people taking care of grandchildren received money from their chil- } \\
\text { dren. Three pensioners received a grant of R650.00 per month, whilst the mothers (n=8) } \\
\text { with children aged less than } 7 \text { years received maintenance of R140.00. The people do not } \\
\text { have many assets. Apart from the house they live in, a television, maybe a fridge and a } \\
\text { radio, they do not own anything else. Nobody reported having any savings. }\end{array}$ \\
\hline Geography & $\begin{array}{l}\text { The farm receives an average rainfall of } 780 \mathrm{~mm} \text { per year, mainly during the months of } \\
\text { October until March. The climate is moderate. The farm is considered the warmest in the } \\
\text { district. Constraints to farming are either droughts or hail. Frost only occurs on the lowest } \\
\text { parts of the farm and snow about every year during June, July and August. }\end{array}$ \\
\hline Resources & $\begin{array}{l}\text { All village members (farm residents) have access to land for cultivation on a small/ } \\
\text { household scale. There are also sheds for cattle, and poultry runs. Some members do } \\
\text { own some implements like forks, spades, wheelbarrows, and hoes. } \\
\text { A well/borehole 200m away is the only communal water source, and although they have } \\
\text { unlimited access, the only way is to fetch it with buckets and carrying it back home. Elec- } \\
\text { tricity is available, although the people have to buy coupons. They mainly use it for light } \\
\text { during the evenings. Wood fires are used for cooking in separate cooking rooms } \\
\text { (kitchens). }\end{array}$ \\
\hline Infrastructure & $\begin{array}{l}\text { The village is situated next to a secondary road (R711) between Fouriesburg and Clarens, } \\
\text { and community members make use of public transport to visit either of the towns. }\end{array}$ \\
\hline Services available & $\begin{array}{l}\text { An informant revealed that a crèche for the farm labourers' children existed previously, but } \\
\text { unfortunately is no longer operational. There is a primary school on the premises, the } \\
\text { nearest high school being in Fouriesburg. The primary school serves } 48 \text { children from dif- } \\
\text { ferent surrounding farms, teaching grades } 1 \text { to } 6 \text {. } \\
\text { After-school care is non-existent, but also not necessary since the school is next to the } \\
\text { village with the majority of adult women unemployed, staying at home. Grandparents take } \\
\text { care of children when mothers are working. } \\
\text { There are primary health care clinics in both towns, and a mobile clinic visits the farm } \\
\text { regularly. The following services are rendered at these clinics: treatment of minor ailments, } \\
\text { tuberculoses, chronic diseases, family planning, integrated management of childhood ill- } \\
\text { nesses, voluntary testing and counselling for HIVIAIDS and sexually transmitted diseases, } \\
\text { immunizations, health education, mental health services, and maternity services. Routine } \\
\text { vitamin A supplementation and deworming of children are also done. } \\
\text { The nearest hospital is in Bethlehem, } 60 \mathrm{~km} \text { away. } \\
\text { A spaza shop is available, selling sweets and icicles to the children. }\end{array}$ \\
\hline
\end{tabular}




\section{BOX 2: NUTRITIONAL INFORMATION}

\section{NUTRITIONAL STATUS}

Dietary patterns

\section{Food production and availability}

Household food gardens are present. Foods planted include mainly vegetables (spinach, pumpkin, potatoes, beetroot, cabbage), fruit (peaches, apricots), and maize. When drought is not a restriction, they also collect indigenous green leafy vegetables (morogo) from the field. Agricultural varieties like thepe, sepidse, and sethokojane (see Figure 3) are present, as well as roots like moputswe and sewediwetla. The men hunt rabbit with their dogs, but these and other wildlife have become scarce. Guinea fowls (gaka) are present on the farm but eaten only during dry and hungry seasons.

\section{Food practices}

Foods most often eaten are maize porridge (mealy meal), milk, poultry (only on weekends or during special occasions), and certain vegetables (spinach, pumpkin, potatoes, beetroot, cabbage). Some households do own cattle, but the farm owner limits them to only four animals per household. Some of the households $(n=3)$ indicated that they do milk the cows, but more often buy milk from the farm owner. If ever a surplus cow's milk is present, they sell it to the Basothos from Lesotho, the neighbouring country. All farm workers receive a bag of maize meal (mealy meal) as part of their allowance/wage. Large families receive eighty kilograms and smaller ones receive $60 \mathrm{~kg}$. All households own chickens. Although chicken eggs are available, the household members rather hatch them, and buy new eggs for eating.

Only two household members reported that they followed the practice of giving preference to adult males in a household regarding food distribution. Males feel, especially when they are working (doing physical labour on the farm), that there should be meat present in their lunch boxes. "We feel ashamed if there is no meat", was one response. No meat to eat is seen as an indication of inferiority and that "things are not well at home".

Some food taboos are still practiced, the main one being the exclusion of eggs from the diets of young girls during their initiation stage. Only married women are allowed to eat eggs. When pregnant and breastfeeding, women again abstain from eggs. Eating chicken intestines, especially chicken kidneys, is also not allowed during these life stages. Special food is usually prepared for funerals. They incur huge expenses for the slaughtering of sheep or cattle for the occasion.

\section{Food preservation}

The interviewees reported to practice solar drying of leafy vegetables, mainly for the winter season, and if there is any surplus left. The elderly women in the community also bottle and dry peaches at the end of the season. Food is preserved mainly for household consumption. The quantities involved do not allow any selling.

\section{Clinical examination}

Apart from symptoms of iron-deficiency (as indicated by a pale conjunctiva of lower eyelid, and pale nail beds), no other prominent physical signs and symptoms were observed in the children.

Anthropometric indicators $(n=20)$

Twenty children between birth and 10 years were measured.

The w-a of seven children (58\%) fell under the 50th percentile, with only one under the 5th percentile.

The h-a of 10 children $(83 \%)$ was under the 50 th percentile. Three children $(25 \%)$ fell under the 5 th percentile.

The w-h of three children (25\%) was under the 25 th percentile.

\section{HEALTH STATUS}

The community members reported two deaths during the visited period - a male who had a stroke and a teenager with kidney failure. Growth charts of children were available, except in cases where the families had migrated from the cities. The problems indicated on the growth charts were an outbreak of scabies 5 years ago, some infections, and only one case of severe diarrhoea and vomiting. One woman (67 years of age) was very underweight. Nobody seemed to know what exactly was wrong with her.

No other cases of severe illnesses and diseases were observed or reported.

The mothers of young children reported to have breastfed their infants up to an age of two years. In two cases, the mothers indicated that they had given infant formula as supplements.

A baby was born during the research period - the mother also breastfed her exclusively up to the age of six months.

NUTRITIONAL INFORMATION continues on page 53 
BOX 2: NUTRITIONAL INFORMATION (Continued from page 52)

\begin{abstract}
HOUSEHOLD FOOD SECURITY $(n=13)$
Thirteen participants reported feeling food insecure, as indicated by an average score of $59 \%$ in the assessment scale.

Average incomes of R600 per month per household were calculated.

The people do not have many assets. Apart from the house they live in, a television, and perhaps a fridge and a radio, they do not own anything else. Nobody reported having any savings.

\section{HYGIENE AND SANITATION PRACTICES}

Scoring $(n=13)$

Instruments were constructed from the literature according to criteria to measure and observe practices. All participants obtained a very low personal hygiene score $(x=2.6 / 10)$; a low household hygiene score $(x=4 / 10)$; and a low environmental hygiene score $(x=4.7 / 10)$.

Participants attained a good sanitation knowledge score, however $(x=78 \%)$, as well as a good sanitation behavioural score $(x=77 \%)$ as measured by separate tests.

No particular illnesses related to food consumption were reported.

\section{Observations}

The following practices regarding hygiene and sanitation were observed and noted:

Pit system toilets were present in the village, and were built by household members themselves. Most of the households own dogs, which appeared undernourished. Chickens were allowed free access to most areas. Very small children were not wearing any nappies, and the smell of urine was very strong in certain houses. All children appeared very dirty. All the houses, except one, were filthy and desperately in need of cleaning. Washing of clothes was done either directly at the borehole, or in front of their houses in tin baths. Nearby wire fences were used for hanging out washing to dry. Garbage was disposed mainly by dumping on a communal site. No signs of burned garbage were observed, although the respondents indicated that they do practice burning and burying of disposed material. The environment around and close to the village was not kept neat and clean. Paper, plastic bags, old toys, implements and pieces of wire fencing were polluting the area.
\end{abstract}

\section{Microbiological tests}

Rodac plates were all overgrown, indicating more than 300 bacteria per $\mathrm{cm}^{2}$ for various surfaces in the households, including mugs, plates, dining room tables, toilet seats, kitchen cloths, hands, clothes and food preparation bowls.

A second microbiological analysis assessed high coliform counts ( $>300 \mathrm{cfu} / \mathrm{ml}$ ) as well as the presence of $E$. coli. Analysis of water samples did not indicate any contamination, either from the source of water, or from the containers being used. Some food samples were also analysed to determine the presence of the most commonly recognized pathogens associated with food. Listeria monocytogenes was detected on one of the eggshells, while Bacillus cereus was detected in one of the eggs. The presence of Staphylococcus aureus on the chicken meat also indicated a lack of personal hygiene practices (Prinsloo, 2003). 


\section{BOX 3: FURTHER OBSERVATIONS REGARDING HYGIENE AND SANITATION PRACTICES} (done at a separate occasion)

"The people don't practice personal hygiene, don't wash themselves, don't brush their teeth, and don't wash their hands after defecation. Children do not use the pit latrines but go the field."

Faeces were observed within 5 meters from the houses. The children were sent to the field by their parents when in need to urinate or defecate. Most of the times the children were not accompanied by any adult. Grass (lengana) or cardboard was used to clean anal surfaces.

Dustbins were not used by any of the households to collect garbage. People used plastic bags in stead, which are thrown on a communal site. Again, no signs of burying or burning of disposed material were observed. The wind also scattered some rubbish through the veld.

Animal droppings were observed all around the village. Only 4 of the 18 households attempted to keep their yards clean, sweeping with grass brooms.

Dogs are not always kept at bay, and were allowed to enter the cooking area.

All the children appeared very dirty, and were wearing dirty clothes. They also indicated that they had not bathed within that particular week.

During food preparation times, no surfaces were cleaned when fresh vegetables were cut. Hands were also not washed before preparation started.

In one household, the feeding of a 6-month baby was observed. The caretaker cleaned the child's dirty nappy, and directly started to feed her again, without washing her hands in-between. The baby food was also left uncovered, with flies all around the food. Within the same household, buckets with drinking water without lids were seen, and people eating from the same dish with dirty hands and dirty nails. Dogs were lying next to the preparation area.

People indicated that they do not have money to buy soap. When they cleaned, they only used cold water. Sometimes, when dishes and pots are washed, the water may be warmed. Pots were not scrubbed, and no abrasive such as 'steel wool' or any other replacement was observed.

In one particular house, the bed and laundry were very dirty. A child was observed with visible worms dripping from the nose. The child also had dry dermatitis, oedema, and skin lesions. The house was described as "smoky and smelly". Only 4 of the 18 houses could be described as domestically clean, based upon the observed criteria (see Table 3).

With regard to the usage of drinking water - hands were touching the drinking water when mugs were used to scoop. No spoon with an extended handle was observed to prevent hands from touching the drinking water.

The day of the visit was also communal 'washing day'. Four women were observed at the communal tap, boiling water in a conga. The children brought the dirty laundry, which was hand washed with powder soap and left to sun dry on the fences. The washing water in the basins was very dirty. 
search team for what they are and have come to do. The research team get to know the people and their circumstances.

Community members get to a point where they can identify and describe their own needs.

The research team members are able to address the identified needs with a community-based intervention.

The following data-collecting methods were used during the contact-making phase of this study, namely individual interviews, observations, and group discussions. Ideographic research strategies attained preference, with no intention to generalize findings to a larger population.

Individual, informal interviews Interviews were conducted, mainly because of the low literacy level of the study population. The interview situation is unknown to the majority of African rural people (Babbie \& Mouton, 2001:249) and the interview may therefore be expected to be quite different from the typical Western situation. Introductions are usually lengthy, discursive and probing. It may for instance take some time to establish good rapport. Because the entire research project depended on this establishment, the interviewer was trained to acknowledge this, and to attempt to counter for it as far as possible.

Data gathering also presupposes a certain familiarity with the subject's culture and language. One particular negative aspect concerning the utilization of the interview technique in this study was the aspect of language. This was a cross-cultural study, implying the presence of an interpreter for the largest part. The presence of an interpreter carries its own problems. Interpreters can obscure the true meaning of words and sentences. They can also change answers to suit whatever it is they want the interviewer to hear, especially if they have an interest in the matter. The research team chose and trained a postgraduate student from the same cultural group to act as a field worker and interpreter. The student, as part of the research team, also collected data for her own research project; therefore she also had an interest in the building of good relations with community members. She was further considered independent and unbiased, with a practical knowledge of the content of the study and of the interview technique.

A positive aspect of using in-depth interviews, how ever, is the objectivity of knowledge acquired with specific regard to freedom from bias, inter-subjective knowledge, and the nature of the object. Other strengths and weaknesses associated with this type of interview are functions of the competencies and skills of the person using this tool to elicit the required information. A good relationship with the participants is fundamental to good quality data. Aspects that received specific attention were the development of mutual respect, and being sensitive to differences in social class, gender, and ethnicity. A reciprocal relationship developed, whereby the research team helped some community members with personal problems. A young girl was raped during one of the visits, and the research team assisted them in arresting the offender.
Babbie and Mouton (2001:291) describes this process of understanding the meaning construction of others as a slow and delicate process. The researcher was sensitive to non-verbal cues from the participants, and noted any change in behaviour, for instance becoming uncomfortable or aggressive. The research team also gave attention to specific accentuated words, the interviewee's attitudes, reactions to what was said, and actions taken. The interviews were also recorded and analysed afterwards, with the assistance of a second interpreter. Results obtained during the contactmaking phase are summarized in Box 1.

Eight women (female heads of the households) voluntarily participated in the interviews. These women represented eight of the eighteen households on the farm. Fifteen other adult females were also included as informants $(\mathrm{N}=23)$. These women were part of a second or third family living with the main household and also seen as caretakers of the young children. They were specifically invited to participate in the group discussions.

Observations While the interpreter directed the interviews, the other members of the research team were involved in observations following a structured observation schedule. Items on this schedule included environmental safety aspects such as the presence of rodents and insects in the food preparation area, personal hygienic practices when preparing food, and the cleanliness of clothes, washing water, and hands. It was also considered vital to make full and accurate notes during these observations (Babbie \& Mouton, 2001:294). Recordings of empirical observations, as well as the team members' possible interpretation of it therefore also formed part of the observation technique.

Group interview technique This was employed as a collective activity to elaborate on the purpose of the study and for further planning. This technique was chosen from the normal repertoire of qualitative research, because it would encourage the involvement of participants, and provided the opportunity for the researcher to investigate further and deeper into the phenomena under study (Babbie \& Mouton, $2001: 292)$. It was therefore compulsory for all the participants in the study to also take part in the group discussions. In the true spirit of PAR, all the women from the village were invited to a group gathering in the school classroom. Fifteen women attended, and each one received an incentive in the form of a vegetable package afterwards. An interview guide provided direction to the discussions. Expression of opinions was encouraged, and the entire process was recorded. The outcome of the discussion was a keen interest in the proposed intervention, and everybody indicating a willingness to participate. The researcher did not create any expectations, but did indicate that the team would come back for feedback and for further planning.

\section{The second level of nutritional information}

The nutrition situation within the community was deter- 
mined in terms of the children's nutritional and health status, household food security, and hygiene and sanitation practices of caretakers and other community members. Individual interviews and observations were once again deployed as research techniques, with caretakers being the main information source.

Nutritional status The nutritional status of the target group was determined in terms of dietary patterns, clinical examination, and anthropometric indicators.

Dietary patterns were investigated using an interview schedule. The following aspects were included:

- Food production and availability.

- Food practices (purchasing, preparation, preferences, distribution, serving, storage).

- Food preservation.

See Box 2 for results.

Basic clinical examinations were done to screen the children for any prominent physical signs and symptoms of nutritional deficiencies. A framework, as proposed by Latham (1997:209-210), was used to guide this activity. Results are summarized in Box 2.

Anthropometric measurements were used to reflect the adequacy of food intake, growth and overall health and welfare. Weight-for-age ( $w-a)$, height-for-age ( $h$ a), and weight-for-height (w-h) indices were used to evaluate the extent and magnitude of malnutrition in the group of young children. These indices were expressed in terms of percentiles, which is the rank position of an individual on a given reference distribution, stated in terms of what percentage of the group is equalled or exceeded by the individual (Lee \& Nieman, 2003:172). International reference data, developed by the US Canters for Disease Control and Prevention (CDC), were used. The w-a of ten of the nineteen children $(53 \%)$ fell under the $50^{\text {th }}$ percentile, with two under the $5^{\text {th }}$ percentile. A low $w$-a is indicative of underweight. The h-a of 12 children $(63 \%)$ was under the $50^{\text {th }}$ percentile, indicative of moderate stunting, whilst three children $(15 \%)$ fell under the $5^{\text {th }}$ percentile, indicating severe stunting. The $w$-h of five children younger than three years were plotted and two of them were under the $25^{\text {th }}$ percentile, indicative of moderate wasting.

Health status Probing regarding health status was also included in the interview schedule. The probes revolved around deaths and diseases within the community, availability of growth charts, and breastfeeding practices. The available growth charts of the children were also assessed for birth weight, growth patterns, and major health problems. The nursing sister of the visiting mobile health clinic was interviewed regarding vital statistics of the district. Results are revealed in Box 2.

Household food security Food security at household level implies physical and economic access to foods that are adequate in terms of quantity, quality, safety and cultural acceptability, to meet each member's nutritional needs. Household food security depends also on an adequate income and assets, in- cluding land and other productive resources. It is ultimately associated with the ability of households or individuals to acquire a nutritionally adequate diet at all times (FAO, 1997:6). This definition therefore implies that safe and nutritious foods should be available and that household resources should be sufficient to meet costs. Household food security therefore relates to aspects of food production and availability, food practices, and food preservation. Secondly, household food security relates to household income and assets, and thirdly it can be described in terms of food safety, including hygiene and sanitation practices.

Household members were asked about their perception of food insecurity, using an assessment scale. This scale was originally constructed by Kendall et al (1995), adapted and used in the National Food Consumption Survey (Labadarios, 2000). The tool is described as a sound national measure for food insecurity and hunger and appropriate for standard, consistent use on national and local levels. The scale is composed of eight questions that investigate whether adults and/or children in the household are affected by food insecurity, food shortages, perceived insufficiency, or altered food intake due to constraints on resources. Answers on each of the eight questions were scored, then summed and converted to percentage. The outcome of the assessment appears in Box 2.

Hygiene and sanitation practices These practices were uncovered mainly by observations. These observations were quantified using three dimensions of personal, household and environmental hygiene. Indicators relevant to each of these dimensions were compiled from the literature (Ahmed et al, s.a: 4-6; Almedon et al, 1997; Billig et al, 1999:13-18; Curtis et al, 2000: 22-32; Daniels et al, 1990:458; Van Wijk \& Murre, s.a.:18). A score was attached to each indicator. Table 1 depicts the scoring guideline. A maximum of 10 marks could be scored within each category, revealing excellent hygienic practices. More than 8 marks were considered to be very good, and between five and seven as good. A score of three or four were indicative of poor hygienic practices, and less than three as very poor.

Hygienic conditions were also determined using total microbiological counts on Rodac plates on various surfaces in all eighteen households, including mugs, plates, dining room tables, toilet seats, kitchen cloths, hands, clothes, and food preparation bowls. Staff from the Department of Food Science and Technology, University of Pretoria, was involved in these measurements. All the plates were overgrown (see Figure 2), that is too numerous to count, but indicating more than 300 bacteria per $\mathrm{cm}^{2}$ for all surfaces. The measurements were repeated two months later where samples were taken from three households. All the samples were analysed at the analytical laboratory of the ARCANPI. The environmental samples (tap handle at the borehole, inside of tap, inside of water containers, table surface, inner and outer surfaces of refrigerators) showed high coliform counts (>300cfu/ml) as well as presence of Escherichia coli, (E. coli) indicating a 
lack of general and personal hygiene practices (Prinsloo, 2003).

\section{Third level of information for intervention planning}

As indicated in Figure 1, information on the third level of the pyramid included (1) nutritional information (from level two), (2) further inquiry into assessed problems, (3) felt problems, and (4) translation of assessed and felt problems into real needs.

Nutritional problems Analysis of information from the second level resulted in the identification of specific nutritional problems. Results are summarized in Box 2. Although sufficient food in terms of quantity were available in the village, the quality and variety was suspected to be a concern. This phenomenon is referred to as dietary diversity. Dietary diversity refers to the number of individual foods or the number of food groups consumed over a given period. The specific measurement and analysis of this problem was another project (Matla, 2004).

Further inquiry The research team decided to do further inquiry into the hygienic and sanitary conditions of the community. The group's knowledge and behaviour regarding these issues were assessed, based on items identified from the literature. The assessment was done informally as a group discussion on the pertinent issues. Thirteen women voluntarily participated.

The sanitation knowledge test consisted of 25 questions on which they could simply respond with a yes or no answer. The sanitation behaviour scale consisted of 25 statements to which they could indicate the degree of agreement (always, sometimes, or never). The possible responses were kept very simplistic, because all these participants were illiterate. They were assisted to indicate their answers either with a cross or a right mark directly onto the paper.

The responses were scored and calculated to percentage. The average total score achieved in the sanitation knowledge test was $78 \%$, and $77 \%$ on the behavioural scale indicating a fairly good knowledge as well as good behavioural intentions. All the participants scored more than $72 \%$ in the knowledge test and more than $62 \%$ on the behavioural scale. The overgrowth of bacteria on the Rodac plates, however, contradicts these scores. An observation technique was therefore employed on a separate, unannounced occasion, whereby the fieldworker did friendly, informal household visits. She was instructed to observe the hygiene and sanitation practices of all the households without recording anything directly on paper. Recordings only took place after each visit. The findings are indicated in Box 3.

Felt or perceived problems These findings clearly showed a need for behavioural change in this regard. The need for improved hygiene and sanitation practices was therefore stated, as the most urgent need to be addressed. A feedback session was held where the community members verified the findings. The community members also expressed other felt needs and concerns. Felt or perceived problems often evolve around improving the economic structure in the short term (Endres, 1999:253), for instance to have or earn more money. Most of the interviewees $(n=10)$ expressed their needs in monetary terms but also indicated a desire for the availability of water directly in their houses, a preschool, and to learn how to sew and make clothes. They also perceived the land available to be insufficient for agricultural purposes. The reason indicated was that the land is against a slope and therefore not good for irrigation.

Translation of assessed and felt problems into real needs Level three also set the stage for the process to follow, namely to obtain consensus and agreement regarding the prioritised needs within the community. Identified and felt problems need to be transformed into real needs that can be addressed. This process cannot commence until at least some people have a positive attitude towards it. Therefore, some of the objectives of the transformation process were to be positive about the upcoming project, not to make empty promises, but to be enthusiastic about what the research team is in the position to offer. The identification and utilization of key informants and various stakeholders was also considered to be useful to assist the transformation process. The community members unanimously elected a group leader during one of the group discussions. The research team considered this lady to be a key informant, and one who was also able to assist in the process of translating the assessed problems into felt needs.

The next step hence called for merging the community's felt and expressed needs and desires with the assessed or identified needs. Assessed needs were identified as perceived food insecurity, insufficient dietary diversity, and insufficient food coping strategies. The research team also needed to find out how the people perceived the assessed needs and started to change any negative feelings people have about their circumstances and their capacity to do something about these needs. Swanepoel (1997:78) said that identifying needs could be a very negative act. People should be led to understand that they should not accept their abjection, but that they should start thinking positively about using their abilities and resources to do something about it. As soon as felt needs are expressed, the urgency of meeting these needs increased. Through the mere act of expressing a need, a person becomes sensitive and aware of such a need. The needs of all members of the community cannot be satisfied at the same time; the result is that several persons become increasingly more dissatisfied with their existing circumstances.

Four discussions at different times were held. With the help of the field worker and key informant, the process of sorting and prioritising problems and needs were set forth. Felt needs and problems (more money, making clothes, water directly available in their houses, a crèche and more land) were beyond the scope of the study as well as the capacity and 
skills of the research team. These needs, however, were discussed with the farm owner. He had certain logistical problems with meeting these needs. The community members were told why certain needs could not be addressed. The research team explained to them what the research team could do. They agreed on addressing the following identified needs personal hygiene and sanitation practices, food security, dietary diversity and food coping strategies. They participated in developing an intervention to address these needs, which included various strategies such as educational materials, games, competitions, household vegetable gardens and processing of surplus food.

\section{DATA ANALYSIS AND INTERPRETATION}

Primary analysis and interpretation was done through discussion and reflection (Babbie \& Mouton, 2001:328; Collins, 1999: 58). Discussion and reflection should, however, be a continuous process and will therefore form the basis of intervention planning and implementation. Data analysis was also mainly interpretative, involving qualitative and quantitative descriptions of the phenomena, and recordings of objective accounts of fieldwork experiences within the specific context of nutrition and the designing of a suitable intervention. Findings were organized and prioritised based on criteria of importance and feasibility, as suggested by Sort (as cited by Caffarella, 1994:89). This process was also tied to the context within which the research study was conducted. Rating them in terms of relative importance and relative feasibility made an overall judgement about the problems or needs. The criteria as stated in Table 2 were used:

\section{CONCLUSION AND RECOMMENDATIONS}

"If a way can be found to meet the identified needs of the community while also satisfying their perceived needs, interventions will succeed" (Endres, 1999:253).

Within the realm of this quotation, a needs assessment was conducted. The initial aim was to conduct a situation analysis, to verify the national finding of the existence of nutritional problems on commercial farms. Certain assumptions underscored this study. Firstly, that nutritional problems were actually present on the farm, secondly, that these problems could be defined as needs within the community, and thirdly, that the community members were willing and competent to be persuaded to address these needs. Specific objectives were stated as to a) describe the community, (b) identify particular needs and problems, (c) translate the nutritional problems into addressable needs, and (d) to establish a basis for designing a suitable intervention.

The community was described in terms of demography, socio-economic profile, geography, resources, infrastructure, and services available (see Box 1). Given the data from the 'needs assessment', the premise was made that nutritional problems are existent on the particular commercial farm under study. These problems were the poor hygienic and sanitary conditions and practices in the community, perceived food insecurity, insufficient dietary diversification, and insufficient food coping strategies (see also Box 2). Felt problems were to have or earn more money, and to learn how to sew and make clothes. Wanting water directly available in their houses, the organization and construction of a preschool as well as the perceived land insufficiency were also mentioned. Through a series of discussions and the assistance of the field worker and key informant, community members came to understand and accept the prioritising of the various problems. The focus of the research team on nutritional problems and the context within which an intervention would be implemented were also explained.

One of the most important outcomes of this needs assessment was a commitment by the research team to actually use the identified needs in the intervention planning process. The following step was recommended to be the design and implementation of a suitable intervention to address the felt needs. The findings revealed from this 'needs assessment', should be used to give direction to the designing and implementing process. The hygiene and sanitation situation within the community should receive priority. Various strategies as stated in the literature (SimpsonHébert \& Wood, 1998:71-93; UNICEF, 1999:51-79; Van Wijk \& Murre, s.a.:7-14) could be considered. A food-based strategy to address perceived food insecurity, insufficient dietary diversity, and insufficient food coping strategies was also suggested. Interventions should be complemented by various nutrition education activities.

A theoretical model should be used as a parameter throughout the designing process. A choice should be made from the vast array available to fit in with the values, preferences, and belief systems of the research team, as well as with the approaches integrated into the research design of the study. More criteria set for the choice of a relevant model should be that it has to be action-orientated, has to address a number of components simultaneously and also has to be flexible enough to be rearranged to suit the demands of the particular situation (Caffarella, 1994:7). This model should particularly be usable to meet the needs of the community.

\section{REFERENCES}

AHMED, NU, ZEITLIN, MF, BEISER, AS, SUPER, CM, GERSHOFF, SN \& AHMED, MA. s.a. Assessment of the impact of a hygiene on environmental sanitation, childhood diarrhoea, and the growth of children in rural Bangladesh. [WWW document 04/16/03]. URL www.unu.edu/unupress/food/8F151e/8F151E07.htm

ALMEDOM, AM, BLUMENTHAL, U \& MANDERSON, L. 1997. Hygiene Evaluation Procedures: Approaches and Methods for Assessing Water - and Sanitation related Hygiene Practices. London. International Nutri- 
tion Foundation for Developing Countries.

BABBIE, E \& MOUTON, J. 2001. The practice of social research. South African edition. Cape Town. Oxford.

BILLIG, P, BENDAHMANE, D \& SWINDALE, A. 1999. Water and sanitation indicator measurement guide. Food and nutrition technical assistance. Title 2. Washington DC. USAID.

BOONE, EJ, SAFRIT, RD \& JONES, J. 2002. Developing programs in adult education. A conceptual programming model. $2^{\text {nd }}$ ed. Waveland. Prospect Heights.

BRADSHAW, J. 1972. The concept of social need. New Society 30(March):640-643.

BUTLER, L \& HOWELL, R. 1980. Coping with growth: community needs assessment techniques. Western Rural Development Centre. Washington, DC. Oregon State University.

CAFFARELLA, RS. 1994. Planning programs for adult learners. Jossey-Bass. San Francisco.

CHOPRA, M \& CLOETE, K. 2001. The community component of the Integrated Management of Childhood IIIness Strategy. Performing a participatory situational assessment. Rome. UNICEF.

COLLINS, K. 1999. Participatory research. A primer. Johannesburg. Prentice Hall.

CURTIS, V, CAIRNCROSS, S \& YONLI, R. 2000. Review: Domestic hygiene and diarrhoea - pinpointing the problem. Tropical Medicine \& International Health 5(1):22.

DANIELS, DL, COUSENS, SN, MAKOAE, LN, FEACHEM, RG. 1990. A case-control study of the impact of improved sanitation of diarrhoea morbidity in Lesotho. Bulletin of the World Health Organization 68 (4):455-459.

ENDRES, JB. 1999. Community Nutrition. Challenges and opportunities. London. Prentice-Hall.

FALS-BORDA, O. (Ed). 1988. The challenge of social change. London. Sage.

FAO (Food and Agricultural Organisation of the United Nations). 1997. Agriculture, food and nutrition for Africa. Rome. FAO.

KENDALL, A, OHLSON, CM \& FRONGILLA, EA 1995. Validation of the Radimer/Cornell measures of hunger and food insecurity. Journal of Nutrition 125:2793-2801.
LABADARIOS, D. (Ed). 2000. The National Food Consumption Survey (NFCS): Children aged $1-9$ years, South Africa, 1999. Pretoria. Department of Health: Directorate of Nutrition. Pretoria.

LATHAM, MC. 1997. Human nutrition in the developing world. Rome. FAO.

LEE, RD \& NIEMAN, DC. 2003. Nutritional Assessment. $3^{\text {rd }}$ ed. McGraw Hill. Boston.

MATLA, MTH. 2004. The contribution of food access strategies to dietary diversity of farm worker households on Oranje farm in Fouriesburg district (RSA). University of Pretoria. Unpublished thesis.

MEISTER, A. 1972. Characteristics of community development in rural animation in Africa. International Review of Community Development 27:75-132.

McKILLIP, J. 1987. Needs analysis - tools for the human services and education. Newbury Park. Sage.

PRINSLOO, NA. 2003. Report on microbiological analysis: Oranje farm. Pretoria. ARC.

ROSSI, PH, FREEMAN, HE \& LIPSEY, MW. 1999. Evaluation. A systematic approach. $6^{\text {th }}$ ed. London. Sage.

SEYMOUR-ROLLS, K \& HUGHES, I. 1995. Participatory Action Research: getting the job done. [WWW document - 06/05/2]. URL http://casino.cchs.usyd.edu.au/arow//reader/rseymour. htm

SIMPSON-HÉBERT, M \& WOŌD, S. 1998. Sanitation Promotion. WSSCC working group promotion of sanitation. Geneva. WHO.

SWANEPOEL, H. 1997. Community development. Putting plans into action. Juta. Cape Town.

UNICEF. 1999. Towards better programming. A manual on hygiene promotion. Water, Environment and Sanitation Technical Guidelines Series - No. 6. New York. UNICEF.

VAN WIJK, C \& MURRE, T. s.a. Motivating better hygiene behaviour: importance for public health mechanisms of change. IRC International Water and Sanitation Centre. The Hague. The Netherlands. New York. UNICEF.

WASSERMAN, I \& KRIEL, JD. 1997. Facts and fallacies. Perspectives on Community Development. Pretoria. Wasserman \& Kriel.

WHYTE, W. 1995. Encounters with participatory action research. Qualitative Sociology 18(3):289-299.

WHYTE, WF. (Ed). 1991. Participatory action research. London. Sage. 